\title{
The Impact of Societal-Level Institutional Logics on Hybridity: Evidence from Nonprofit Organizations in England and France
}

\author{
Caitlin McMullin $^{1}$ (D) Chris Skelcher $^{1}$
}

Published online: 3 May 2018

(c) The Author(s) 2018

\begin{abstract}
We examine how societal-level institutional logics impact the way in which hybridity develops in nonprofit organizations using international, comparative and qualitative case studies of community regeneration organizations in England and France. The research applies theoretically based conjectures about types of hybridity to empirical data generated from 20 interviews, document analysis and observation in five nonprofits in the city of Lyon and five in Sheffield. We find that the French nonprofits are 'blended' hybrids that integrate state and community institutional logics, while 'assimilated' hybrids combining state, community and market logics are found in the English cases. Undertaking contextually situated analysis of institutional logics generates new knowledge on the influences on nonprofits' rules, practices and narratives, so improving the level of knowledge about, and capacity to manage, this sector.
\end{abstract}

Keywords Nonprofit - Institutional logics · Hybridity · England $\cdot$ France

\section{Introduction}

Nonprofit organizations are increasingly described as 'hybrids,' which blur the traditional boundaries between the public, private for-profit and community sectors (Billis

Paper submitted to Voluntas for special issue on The Organizations of Civil Society.

Caitlin McMullin

caitlin.mcmullin@gmail.com

1 Institute of Local Government Studies, University of Birmingham, Muirhead Tower, Birmingham B15 2TT, UK
2010). However, the concept of hybridity has primarily been used as a description in the nonprofit literature and limited attention has been paid to (1) theorizing and explaining how and in what ways hybridity develops in nonprofits and (2) whether, and if so how, the forms of hybridity found in different countries vary. This paper addresses these gaps by employing the theory of institutional logics in a cross-national study, thus critically assessing whether this approach can contribute to greater understanding of how hybridity develops in nonprofit organizations. We analyze data gathered from research conducted with community regeneration organizations in England and France, in order to address the following research question: How do different combinations of institutional logics in England and France shape the types of hybridity exhibited by nonprofit organizations?

England and France present compelling cases for comparison. Both countries have large and vibrant nonprofit sectors, but may also be seen as 'most different cases' in terms of welfare regimes, institutional configurations and governance traditions (Esping-Andersen 1990; Bevir et al. 2003). Given these contextual and cultural differences, we hypothesize that the French and English organizations will thus be driven by different combinations of institutional logics and will therefore exhibit different types of hybridity. This paper is structured as follows. The next section reviews the theoretical literature on hybridity, nonprofits and institutional logics in order to establish a framework for the analysis. Section three describes the research design and methodology and explains the community regeneration contexts in Sheffield and Lyon, the two cities in which the case study organizations are located. Section four presents the analysis of institutional logics and hybridity in the two locations, followed by the development of a model of institutional logics and hybridity informed by Skelcher and 
Smith (2015). Finally, we identify four ways in which this research contributes to the study of nonprofit organizations.

\section{Theoretical Context}

\section{Hybridity and Nonprofit Organizations}

Developments in the nonprofit world, as much as in government and business, have stimulated the development of a greater diversity of organizational forms and modes of behavior. In the nonprofit sector, hybridity typically refers to the complex organizational forms that arise as voluntary, charitable and community organizations confront differentiated task, legitimacy or resource environments. Minkoff's (2002) study of nonprofits that combine service provision and political advocacy provided an early study of this development. More recently, Smith (2014) has documented the blending of what were considered to be incompatible approaches into 'hybrids'-for example, a nonprofit service delivery organization creating a for-profit trading subsidiary as a solution to the need to identify new sources of revenue to fund their core mission (Cooney 2006). Other scholars have examined the effects of contracting-out by government for delivery of public services, which can range from social care functions to the more contentious outsourcing of the core public protection functions of the state such as supervision of offenders (e.g., Binder 2007; Evers 2005; Mullins 2006; Knutsen 2012). These forms of hybridity can generate tensions within a nonprofit between meeting government's contractual requirements and sustaining the original social mission.

Surveying the whole field, Brandsen et al. (2005, p. 758) argue that 'hybridity [is] an inevitable and permanent characteristic' of the nonprofit sector because the domains of market, state and civil society can no longer be classified in a mutually exclusive way, thus making it difficult to create an unambiguous definition of the nonprofit sector. But as Skelcher and Smith (2015) argue, the nonprofit literature has tended to employ the concept of hybridity descriptively, for example in discussing organizations that combine features of altruistic social welfare with commercial principles of trading, and there has only been limited theorization about the development of this state (e.g., Billis 2010; Hasenfeld and Gidron 2005; Jäger and Schröer 2014).

This insight helps motivate the study reported here, which employs a nonstructural approach-institutional logics-in order to analyze and theorize developments in nonprofit organizations. Conceptualizing hybridity in this way removes the analysis from the taken-for-granted assumptions about the characteristics of government, business, civil society and nonprofit organizations. Instead, the object of enquiry becomes the way in which the interactions between plural institutional frames or 'logics' impact on the way in which the organization and its employees, clients and trustees understand their operating environment and construct responses to it.

\section{Institutional Logics}

Institutional logic refers to the cultural beliefs, norms of behavior and rules that inform decision making within organizations (Lounsbury 2007). These are both material, in terms of organizational structures and practices, as well as symbolic, relating to assumptions, beliefs and identities within organizations (Thornton et al. 2012). In other words, an institutional logic is 'the way a particular social world works' (Thornton and Ocasio 2008, p. 101). Theoretically, institutional logics are generative of organizational legitimacy and actor identity through the creation of symbols and practices (Friedland and Alford 1991).

Institutional logics are conceived as the main 'institutional orders' of society, which Friedland and Alford (1991) argue consist of capitalism, family, bureaucratic state, democracy and Christianity. Subsequent work by Thornton et al. (2012) builds upon this typology by suggesting seven ideal typical institutional orders-family, religion, state, market, profession, corporation and community. Each of these institutional orders is characterized by a particular mix of values, assumptions and structures that form its dominant logic or operating principles. The theory of institutional logics proposes that organizations will be impacted and to some degree shaped by the logics extant in their field. This perspective is central to the emerging literature on hybridity since it helps to explain the possible outcomes when an organization faces plural logics and the resulting tensions and contradictions between them (Kraatz and Block 2008).

This approach is particularly appropriate for studying nonprofit organizations since they typically have to negotiate the tensions between sustaining themselves in financial and mission terms and the addressing the expectations of stakeholders in their operating environment. As indicated above, this has resulted in a growing nonprofit literature employing the institutional logics approach. For the purposes of our study of community regeneration nonprofit organizations, we focus on the state, market and community logics as these bear most directly on their role. In addition, recent nonprofit literature regards these as most relevant to the study of hybridity in this field (e.g., Vickers et al. 2017). The state logic is defined by an emphasis on democratic participation and the redistribution of resources through bureaucratic channels to increase community welfare. The market logic is characterized by the motivation of profit and efficiency through selling goods and 
services. Finally, the community logic emphasizes legitimacy arising from local trust and reciprocity, and the cooperation between individuals within a shared geography or common set of values (Thornton et al. 2012).

Skelcher and Smith (2015) propose that plural logics may be generative of different types of hybridity. Their five theoretically derived propositions are: (P1) Segmented and (P2) segregated hybrids which occur, respectively, when organizations compartmentalize elements of different logics within an organization, or into separate but associated organizations. (P3) Assimilation of plural logics may occur in response to the authoritative imposition of a new logic upon a nonprofit organization (Pache and Santos 2013), resulting in strategies to manage the resulting tensions and ambiguities (Reay and Hinings 2009). However, (P4) blended hybrids respond to multiple logics by combining them into new forms that bridge the gaps between differing identities, practices and values, as in the case of social enterprises which blend market, community and state logics into a new type of business oriented to improving community or social conditions through the sale of products and/or services (Battilana and Lee 2014). Skelcher and Smith suggest this is likely to occur where organizations face a high degree of turbulence in their environment. Finally, (P5) blocked hybrids result when organizations are unable to reconcile the different features of logics in their field, resulting in organizational dysfunction.

\section{Defining Institutional Logics}

We operationalize the concept of institutional logic by drawing on Thornton and Ocasio's (2008, p. 101) view that they are 'the socially constructed, historical pattern of material practices, assumptions, values, beliefs, and rules' which, in Lounsbury's (2007, p. 289) terms, 'structure cognition and guide decision-making in a field.' These definitional elements were chosen to highlight, first of all, the emphasis that Lounsbury places on the broader organizational responses to logics (as opposed to the agentic role of individuals), and secondly the three key components of (1) rules, (2) practices and (3) assumptions, values and beliefs which we employ in order to gather and analyze our data.

Rules encompass the formally recorded regulations, procedures and laws that constrain and enable actors within institutions (Scott 2014), including the requirements included in the contracts and funding arrangements that are common in the nonprofit field. Practices refer to the informal 'rules of the game' - the behaviors, actions and routines that are deemed to be acceptable in an organization (Lowndes and Roberts 2013). Practices are important because they signify human agency in structuring institutions, and studying these allows us to better understand the everyday lived experiences of actors, and how and why the institution is mobilized in particular ways (Reckwitz 2002; Feldman and Orlikowski 2011). The final element-'assumptions, values and beliefs' - can be seen as analogous to the 'cultural beliefs' or 'symbolic constructions' described by theorists (Lounsbury 2007; Friedland and Alford 1991). These compose the nonmaterial elements of institutional logics, or the ways that practices and rules are made meaningful by actors. In order to identify these symbolic elements, we have operationalized assumptions, beliefs and values by analyzing actors' narratives. Narratives are the spoken expression of ideas and the way that practices are justified by actors in order to create shared understandings and allow us to identify how they make sense of the world, their motivations for particular actions, and their values and beliefs (Feldman et al. 2004).

\section{Research Design and Methodology}

\section{Case Studies}

The research design involves a comparative analysis of most similar organizational cases and cities within two contrasting countries. This two-level case study structure enables us to undertake an empirical investigation in which the objects of the analysis (the city-based organizations) are held constant, while the logics applying to them are contextually diverse. As a result, we aim to expose Skelcher and Smith's universalistic and theoretically derived propositions to a critical, empirically situated analysis. Theoretical sampling was used to select the two countries-France and England-which represent most different cases at the macrolevel (Hantrais 2008) and in terms of the state, market and community logics on which we focus.

France is predominantly categorized as a corporatist welfare regime and nonprofit regime, with high welfare spending coupled with social welfare entitlements generally based on contributions to insurance, and a large nonprofit sector that plays a significant role in the delivery of publicly funded social services. Nonprofits are considered to be part of the 'social and solidarity economy,' which encompasses a broad range of cooperatives, unions and associations that aim to democratize the economy and benefit society (Evers and Laville 2004), creating a community logic that is defined by the rules of formal democratic procedures supported by a narrative of solidarity. The UK, by contrast, is considered a liberal welfare regime and nonprofit regime, where social welfare benefits are comparatively modest and means-tested, and the sizeable nonprofit sector remains largely independent from the state (Esping-Andersen 1990; Salamon and Anheier 1998). The community logic, then, is comparatively more focused on 
the informal practices and narratives of cooperation and collaboration within particular communities.

Furthermore, when considering governmental traditions, or the structures and values that characterize public administration and government (Peters 2008; Bevir et al. 2003), France is categorized as Napoleonic, with a hierarchical, centralized state that exists to unify society, while the UK as part of the Anglo-Saxon tradition is defined by societal pluralism and the privileging of the individual over the state. As such, the state logic in France is informed by rules and hierarchy, while in the UK, this logic is more defined by negotiation and informal practices. In addition, the introduction of New Public Management principles in the UK has led to the increasing prevalence of the market logic within the nonprofit sector, while France has seen relatively little impact of NPM (Rouban 2008).

Our study focuses on one city in England and one city in France. Sheffield and Lyon were selected because of size comparability (both with a population of about 500,000). While Lyon is traditionally recognized as a bourgeois city and Sheffield as working class, both cities have a strong tradition of union and cooperative formation and membership, linked to their manufacturing sectors (silk and steel, respectively). In each city, we have selected five nonprofit organizations that provide comparable services within the community regeneration/community development sector. The decision was made to focus on community regeneration organizations because, first of all, there are a relatively large number of these organizations operating in both cities, and secondly, because each organization is multifunctional, providing a range of different types of services. This enables a degree of cross-case comparison that is not limited to a small subsector of nonprofits.

In Sheffield, the community regeneration organizations each own community assets (such as community centers, gyms and offices) and deliver a range of health, education, training, employment and other community services across different, relatively deprived areas of the city. In Lyon, the comparable organizations in the community regeneration sector are called 'centres sociaux,' which we have chosen to roughly translate as 'social centers' because they are distinct entities from the more general 'community center' in English. It is important to note that 'social' in this context refers to the improvement of the social conditions of deprived populations, e.g., 'social services,' rather than the more general definition of fraternization, e.g., 'social club.' Each social center operates from at least one central community building, which house facilities for fitness classes (yoga, kung fu, etc.), classes for adults and children (such as French classes, homework help for young people and work clubs), social activities (cooking workshops, book clubs) and childcare facilities. The organizations are summarized in Table 1.
Organizations in Sheffield were chosen through reputational and snowball sampling, by asking local networks and stakeholders for recommendations and building upon contacts. The three largest community regeneration charities were selected, as well as two medium-sized organizations. In Lyon, there are 16 social centers in operation, all of whom we contacted by email to participate in the research. We were successful at recruiting five of these organizations, which are located in dispersed neighborhoods around Lyon.

\section{Data Collection and Analysis}

A total of 20 interviews were undertaken, with the directors/chief executives of all 10 organizations, and frontline staff members and volunteers at five of the organizations (four of the Sheffield organizations and one in Lyon). Staff and volunteers were selected on the basis of recommendation from the directors. Interviews were audio recorded and transcribed verbatim. In Lyon, interviews were conducted in French, except with one director who was fluent in English. Respondents were asked about their organization's strategies, values and day-to-day activities. While there is a risk of relying on accounts of individual interviewees and their ability to objectively describe day-to-day practices and behaviors, the risk of bias has been minimized by triangulating the narratives of respondents with an analysis of organizational documents (such as mission statements, strategic plans and annual reports), and through attending and observing annual general meetings (three in Lyon, two in Sheffield) and activity days (one in Lyon, three in Sheffield). Particular attention was paid to triangulating the data with other methods (documents and observation) in the cases where only the director was interviewed.

The research takes an abductive, iterative technique to collecting, analyzing and interpreting the data. By this, we mean that while we began with a broad idea of the theory to guide the analysis, we allowed new themes and ideas to emerge and coalesce (Timmermans and Tavory 2012). Thus, while embarking on the research with some tentative hypotheses about the influential logics in the two countries based on institutional typologies, we do not assume a priori knowledge of the logics that exist within the case study organizations or types of hybridity created by these, instead using the coding and interpretation to develop these.

Interview transcripts, field notes and organizational documents were coded using NVivo according to our operationalized definition of institutional logics for rules, practices and narratives. Following this, a second round of coding was undertaken according to the descriptions of ideal-typical institutional orders described by Thornton et al. (2012). Where we found passages that were coded 
Table 1 Case study organizations

\begin{tabular}{|c|c|c|c|c|}
\hline Organization & $\begin{array}{l}\text { Year } \\
\text { Est. }\end{array}$ & Staff & Facilities & Services \\
\hline Sheffield A & 1998 & 58 & $\begin{array}{l}\text { Purpose-built facility with } \\
\text { commercial workspace }\end{array}$ & $\begin{array}{l}\text { Public health initiatives and employment support, nursery and youth club, } \\
\text { support two local community forums }\end{array}$ \\
\hline Sheffield B & 1998 & 35 & $\begin{array}{l}\text { Building that houses a library and } \\
\text { housing advice services }\end{array}$ & $\begin{array}{l}\text { Large range of health and well-being services (e.g., counseling, health } \\
\text { trainers), employment services (e.g., job clubs) and training }\end{array}$ \\
\hline Sheffield C & 1998 & 78 & $\begin{array}{l}\text { Leisure center, café and volunteer- } \\
\text { run library }\end{array}$ & $\begin{array}{l}\text { Large range of health, employment, social and leisure activities for adults } \\
\text { and children }\end{array}$ \\
\hline Sheffield D & 1999 & 21 & $\begin{array}{l}\text { Second-hand shop, community } \\
\text { hub, online center, library }\end{array}$ & $\begin{array}{l}\text { Job clubs/employment support and training, social activities for older } \\
\text { people, health trainers, management of a small library }\end{array}$ \\
\hline Sheffield E & 1997 & 14 & $\begin{array}{l}\text { Manage a council-owned } \\
\text { community facility (former } \\
\text { school) }\end{array}$ & Work clubs, adventure playground and community organizing \\
\hline Lyon A & 1972 & 26 & Community center & $\begin{array}{l}\text { Social activities for all ages. Majority of focus on activities for older people } \\
\text { who make up a large percentage of the membership }\end{array}$ \\
\hline Lyon B & 1967 & 57 & $\begin{array}{l}\text { Moving between facilities at the } \\
\text { time of the research }\end{array}$ & $\begin{array}{l}\text { Crèche, activities for youth and families, administrative support and advice } \\
\text { for local neighborhood groups }\end{array}$ \\
\hline Lyon C & 1957 & 90 & Community center & $\begin{array}{l}\text { Social activities for all ages, education support for youth, training } \\
\text { (employment, French language) for adults }\end{array}$ \\
\hline Lyon D & 1972 & 62 & Three community centers & $\begin{array}{l}\text { Crèches and activities for children, training and support (e.g., French } \\
\text { language, computer classes) for adults }\end{array}$ \\
\hline Lyon E & 1990 & 43 & Two community centers & $\begin{array}{l}\text { Youth clubs, homework help, leisure activities for all ages. Majority of } \\
\text { focus on youth and children }\end{array}$ \\
\hline
\end{tabular}

with two or more logics, we coded these as exhibiting either assimilation, blending or conflict (Skelcher and Smith 2015). This approach allowed us to determine not only the existence of plural institutional logics, but also the degree of complementarity or discord between these logics. All quotes from interviewees have been anonymized to protect participants' identities.

\section{Analysis-Institutional Logics and Types of Hybridity}

As noted in the review of the institutional logics literature, the analysis concentrates on the interplay between the three dominant logics-community, state and market-which are theorized to be the most influential in the nonprofit sector. Our data analysis validated the prevalence of these three logics, but we also identify a subsidiary logic that we term the 'professional' logic. The analysis in this section proceeds as follows: we discuss the Lyon and the Sheffield case studies in turn and analyze the ways in which these organizations interpret and respond to different and sometimes contradictory logics.

\section{Social Centers in Lyon}

\section{Rules}

The logics of the organizations in Lyon are strongly influenced by formal, recorded rules that are defined and imposed by the national government, the National Federation of Social Centers and each organization's own policies and procedures. These rules take the form of national laws, charters and organizational plans, which concurrently serve to define the social centers' governance structures.

In order to be designated as a social center, each association must sign the National Charter of Social Centers (Charte fédérale des centres sociaux), a document that defines the purpose and values of its constituent organizations. Signing the charter means agreeing to adhere to three founding values-human dignity, solidarity and democracy_and espousing a mission to support local people to define a plan of social development (projet social) for the local area. The directors of all five social centers defined their organization using similar terms derived from the National Federation of Social Centers:

The social center is a structure that is defined by its plan and by its territory. [...] And the third pillar of the definition of a social center is the democratic functioning. That is to say, it's an associative structure that is run by a general assembly with volunteers 
who function under a democratic model. All social centers have these three axes - a plan, a territory, democratic functioning. (Director, Lyon C).

In the rules created by this charter, the boundaries between the logic of the state and that of the community are blurred. In contrast to the model of the nonprofit sector in the UK, the associative model in France is defined by the importance of rendering the rules of the state-in particular, those around democracy and citizenship_into a local context through associations. Social centers are legally independent organizations from the government, but the structures and rules that form the state logic retain commensurate importance to the rules that define the community logic (e.g., the constraint on nonprofit organizations from redistributing profits to owners or members).

Social centers' logics are also defined by the rules created by a national government policy called the Politique de la Ville, a national urban renewal program that targets areas of disadvantage through partnership building between public powers and civil society. This policy has been extremely influential to at least three out of the five social centers in terms of providing funding, but also in driving a nationally defined agenda relating to social cohesion, citizen participation and regeneration in deprived areas.

In 1981, there were important social movements that arose in difficult neighborhoods, and then we saw a specific political direction with well defined criteria and specific funding for these districts that were defined as part of the Politique de la Ville. (Director, Lyon E)

We are the only social center, the only association in Lyon to say, 'We want to support the creation of the citizen council in a neighborhood here that is a Politique de la Ville neighborhood.' (Assistant Director, Lyon A)

Here, we see again that the defined rules do not belong clearly to either the state logic or the community logic. On the one hand, the state logic comes through clearly in the fact that this policy is defined by national government with the intention of redistributing resources in the public interest. However, the community logic is blended with this state logic, as described above in the fact that the policy was originally conceived in response to actions of a social movement, as well as the fact that improving deprived neighborhoods is both a community as well as a government objective.

Internal rules, particularly those surrounding governance structures, are also a key element of the logics embedded in the social centers. Social centers are governed by elected boards of trustees (conseils d'administration), who must be local residents (as opposed to representatives of other local community groups who may actually be paid staff of those groups, which is often the case for the boards of trustees of many British charities). The board of trustees was described by several of the respondents in Lyon as playing an important role in defining the direction of the social center (interviews 1, 2, 3, 4, 5 and 8). Similarly, the yearly assemblées générales (general assemblies) are often well attended and seen by social center directors and staff as a key event in order to determine the strategies and priorities of the organization.

\section{Practices}

While rules are formal, codified restrictions and constraints on behavior, practices are the day-to-day actions or 'informal rules of the game' that are exhibited and normalized by actors. Practices were identified through observation of three of the five social centers' AGMs and through analysis of strategic plans and interview transcripts. Identifying practices from documents and interviews alone is somewhat problematic, as this relies on an analysis of formal recorded material in the first case, and the recall and interpretation of individuals in the second case. We therefore recognize the limitations of our data and approach the data with a degree of caution insofar as we can accurately deduce the practices that take place within normal organizational operations.

One of the key practices of the social centers is the involvement of volunteers, staff and trustees in the creation of five yearly strategic plans. Local residents are also part of the plan preparation process, which was often described as a process of 'co-construction.' This involvement of local people in defining the strategic direction of the social centers reflects the importance of the community logic in organizational practices.

We do what we call a diagnostic. [...] We did a questionnaire [of our members]. And then, in the neighborhood, we had two questions about what you appreciate in your neighborhood. Are there good things? Bad things? What do you think is good, what is bad? Who or what is helping you? Then after, do you come to the social center? We try to work with the strong points and the weak points of the area. (Director, Lyon E)

This type of process to develop social or strategic plans was similarly described by the directors of Lyon A, Lyon B and Lyon D. The co-construction that takes place typically involves consultation of local people and/or more innovative efforts to co-design the document (for example, through collaborative art projects). This more informal inclusion of community members' views and priorities is privileged over the bureaucratic dominance or regard for 
democratic voting as the sole legitimate source of decision making that characterizes the state logic.

One of the notable informal practices described by several interviewees was the emphasis on supporting local people to develop their own projects. Within Lyon A, the two volunteers and the director who were interviewed described several projects, such as a 'gratiferia' (market where everything is free) and a weekly community picnic during the month of August when the social center building was closed. Both projects were proposed by local residents and were executed in partnership with staff members. This practice of encouraging local people to design projects and activities that can then be supported with professional help from staff is a key tenet to the way that social centers design their work and, again, reflects the strength of the community logic in defining practices. The support of citizen-led projects does however occasionally come into conflict with the professional logic (which was described by interviewees 2, 3 and 8). Staff members are specifically trained to work within the associative sector, but interviewees described instances where it requires a change of culture and mindset to allow citizens to take the lead in designing and carrying out projects.

\section{Narratives}

Narratives enable actors to justify their actions, and explain why rules exist or what motivates practices. They consist of stories and symbols that individuals use in order to make sense of organizational life, including what is valued and what assumptions and beliefs guide actions (Feldman et al. 2004). The three founding values of the National Charter of Social Centers are human dignity-referring to being inclusive and respectful of cultural differences; solidarity-building social cohesion and neighborliness; and democracy-opting for a governance arrangement that values debate and the sharing of power (Charte Fédérale des Centres Sociaux et Socio-Culturels de France, 2000). These three values framed the way in which the respondents from the social centers narrated their work.

The term 'solidarity' is used frequently by associations on their Web sites and in organizational literature to describe both the reasons for forming the association, as well as to describe the types of services and actions undertaken. This value is expressed as important by actors at the field level (i.e., the National Federation of Social Centers), at the organizational level (such as in the social plans of all five social centers), and by individuals within the organization. Solidarity is described in the plans of two of the social centers as follows:

Solidarity: The social center supports the construction of a space for exchange and sharing, where each local resident has their place. A space where social and intergenerational links are created. (Projet Social, Lyon B)

Solidarity: Considering men and women as showing solidarity with one another, meaning being capable of living together (vivre ensemble) in society, has been a continuing conviction of Social Centers since they began. (Projet Social, Lyon A)

The second quote illustrates how solidarity is also linked with the concept of 'vivre ensemble,' which translates roughly as 'living together,' but can probably best be understood in English as 'peaceful coexistence' or 'diversity' of different groups in society. Vivre ensemble is a uniquely French way of resolving ideas of fraternité, or brotherhood, and solidarité with the reality of an increasingly diverse population. The idea of multiculturalism is difficult to reconcile with the French conceptualization of citizenship, where everyone-regardless of religion or ethnicity-is French and French alone, with no space for different communities within this identity. For example, one of the social centers has as a strategic priority to "promote the "vivre ensemble"':

Reinforcing the act of 'reaching out' to residents, no matter their age or their sociocultural origins.

Adapting our offer to be attentive to different populations (to make 'cultural mixing' work, it's necessary for different people to share the same service or the same activity)[...]

Paying particular attention to welcoming vulnerable populations.

(Projet Social, Lyon E)

Another shared value we identified is laïcité, the particularly French concept of secularism, which insists on a strict separation between religion and public life. This has become a challenge for associations trying to reconcile this notion with religious freedom in increasingly diverse cities.

Some years ago, we had a decision that [...] women with hijab couldn't be a volunteer in our association. So through the discussion, putting people together to discuss, we have been changing this policy. That was really thanks to the participation of different people who are from different origins. That was quite a success. Now we've got volunteers with hijab, still in trying to defend the values of laïcité is important, and that you should not do proselytizing. (Director, Lyon D, interview in English)

These common values-especially solidarity and vivre ensemble-stress the importance of local connections and community embeddedness, which at the surface level 
would suggest a clear mobilization of the community logic. However, one must take into account the particular political traditions of France to understand that these values are in fact a blend of the state and community logic. We have conceptualized the 'community' logic in accordance with Thornton et al. (2012) and others, with a focus on local cooperation, neighborliness, trust, reciprocity and personal investment in a group. Defined in such a way, a large percentage of passages from the Lyon interviews were coded as including elements of the community logic.

However, 'community' is an idea that is perceived as somehow 'not French,' as a representative from a regional network of social centers described-

In France, it's not permitted to talk about 'community' because that refers to the private sphere, and what we share in France in terms of being citizens, that's what must be shared in the public sphere.

It is important to note this baggage associated with the term 'community' in France, where it is associated with communitarianism, seen to be a negative term that is linked with splintering cultural communities that do not adhere to the values of the French Republic. Local difference is typically admonished, rather than celebrated, and the idea of strengthening local communities is viewed as a way to diminish the importance of the state.

The logic of social centers defined by these values and beliefs exhibits a compelling blend between what we would typically define as the state and community logics, but in a decidedly French amalgamation. In many ways, the state logic itself defines the community logic - in the sense that many of the rules, practices and narratives that define traditional community work and associations are the same as those that emanate from the government. The French state, since the beginning of the Fifth Republic, has been strong and centralized, applying uniform policy across the system, and it has traditionally had a strained relationship with civil society. France sees the state as something not only quite separate from civil society, but often actually opposed to it (Laborde 2000). In many ways, associations play the role quite similar to that of the state and are thus inclined to carry logics of both the state and the 'community.'

\section{Community Regeneration Organizations in Sheffield}

\section{Rules}

Compared to the social centers in Lyon, laws and government policy appear to have rather limited importance in defining the rules that constrain community regeneration organizations in Sheffield, except when they specifically relate to contracts or funding. In analyzing the Sheffield interviews, there was in fact virtually no mention of any law or government policy (national or local) that was not directly related to funding. This is likely due to the period during which interviews were conducted (May 2015 to November 2016), a period during which funding programs and policy initiatives that had supported nonprofits in Sheffield were significantly diminishing. The absence of reference to government policies in organizational documents (such as annual reports and operational plans) reflects the weakness of the state logic in regard to formal rules, particularly in comparison with the Lyon social centers. This is indicative of the government's stated intention to devolve powers to local government and to local communities-and it has therefore, in comparison with the French cases, taken an increasingly hands-off approach to legislating local community activities.

A more important source of rules in Sheffield has been their funding arrangements. We have interpreted the concept of 'rules' slightly more broadly to include the requirements of grants and contracts. This decision to broaden the definition of rules was borne from conducting and coding our interviews. While there was limited discussion of the 'standards, regulations, protocols and policies' that Lowndes and Roberts (2013, p. 53) list as examples of formal rules, this did not seem to sufficiently incorporate the range of semi-formal constraints described by interviewees. The guidelines, expectations, targets and requirements of funding bodies appear to inhabit a middle ground between rules and practices-these are sometimes formally recorded (such as in contracts), but sometimes enable and constrain organizations' behaviors through implicit expectations. Despite this ambiguity, we have thus chosen to categorize funding and contracts as rules.

The five community regeneration organizations were founded in the late 1990s as recipients of European Objective 1 funding and large grants from the national Single Regeneration Budget (SRB). Both funding streams aimed to stimulate local economic growth through the creation of partnerships and matched other resources from the private, public and third sectors. Sheffield City Council decided to channel this money into local groups rather than determine funding priorities itself. However, Objective 1 funding was seen as highly prescriptive-

They said for example, you can spend the money up to this point, this geographical point, but not a centimeter beyond that. So you'd get, on a particular street, you might have houses 1-20 that were included in the geographical area that was entitled to Objective 1 money. But then house \#21 was outside so they weren't allowed to benefit. (Director, Sheffield D)

In this example, we see a conflict that ensues between the state logic_-which favors redistribution and overall 
improvement of communities-and the community logic, which in this case reveals a more holistic and communitycentered approach to defining boundaries for the distribution of regeneration money. After several years, these streams of regeneration funding came to an end and organizations were forced to adopt more business-like behavior in order to become self-sustaining. The introduction of a market logic was destabilizing to many of the organizations within the community regeneration sector, who had been established with a clear mobilization of the state and community logics.

When Objective 1 finished, they all sat there, all these committees sat there and went, 'What are we going to do now?' 'I don't know.' About 50\% of them just closed down overnight. [...] We were left with perhaps, I don't know, eight or 10 quite strong groups which had been a bit more forward-thinking and had spread their wings a bit and searched for other sources of funding. (Director, Sheffield D)

This conflict meant that many of the organizations that were founded during the period of large-scale government regeneration funding (not including the five case studies) would be characterized as blocked hybrids (Skelcher and Smith 2015) because they were unable to resolve the conflict between incompatible institutional logics. The organizations that endured managed to strategically integrate elements of the market logic (such as contract guidelines and targets) in ways that allowed them to continue to prioritize a more community-driven ethos.

Finally, all five case studies in Sheffield are legally constituted as charities, meaning that they are governed by a board of volunteer trustees who are residents and/or representatives of local voluntary and community groups, elected as per the organizations' constitutions. Though this legal governance structure is comparable to that of the social centers, we did not find the same importance accorded to internal governance and democratic decision making. In this sense, the internal rules in Sheffield can be seen to match more with the community logic than the blend of the community and state logics exhibited in Lyon.

\section{Practices}

The data reveal that all five organizations in Sheffield regarded service provision as their main purpose. Their practices show an assimilation of the market logic with the community and state logics, in prioritizing activities and approaches that produce beneficial outcomes in communities to deliver health, well-being, employment, leisure and social services. The practices or 'informal rules of the game' (Lowndes and Roberts 2013, p. 58) tend to relate to the ways in which services are run and managed, with particular focus on managing scarce resources.

One director described their organization's process for developing new projects and ideas:

We'll look at how that [a new project] fits in with the business plan [...] It will normally be the case that such an idea has come out of something that's been said at an event by members of the public. It won't just be us going, 'We would like to do this.' [...] Then we'll draw up an action plan. This all sounds very, very prescriptive, but it's not. [...] Somebody will be going back to the community and saying, 'This is what we've been thinking of based upon some comments from people at the festival three months ago, what do you think? Is it worth pursuing?' (Director, Sheffield D)

This quote is illustrative of the practices described by several of the Sheffield community regeneration organizations. It demonstrates the primacy of the community logic, with efforts made to include community voices into project planning, but also reflects the degree to which community organizations have incorporated the market logic into their practices, aiming to become more business-like in their approach to designing services and projects. We see an assimilation of certain elements of the market logic, such as business and strategic planning, into more communitydriven practices to achieve local improvement.

'Community engagement,' or trying to maintain a dialogue with service users and local residents about the design and delivery of services, is an important feature of the way that the community regeneration organizations in Sheffield operate. The community logic structures the way in which professionals see their role vis-à-vis local people, with co-design or intensive consultation being driven by a desire to better meet people's needs.

Maybe it's the kind of embedded, the thing about the relationship with the clients is embedded in the nature of the relationship we try to develop with the client from the start. Rather than being a kind of formalized, bureaucratic process of filling in forms and all that kind of stuff, it's about the dynamics of the relationship between staff and clients. (Director, Sheffield B)

Respondents often articulated a vague strategy of 'listening and gathering people's views' (staff member, Sheffield C) and 'working with local people' (staff member, Sheffield A), without always delineating exact strategies or plans for doing so. None of the organizations, even the two that define themselves as community development organizations, can be described purely as carriers of the community logic. The reality of community development work is that 
these organizations are still partly funded by the government to deliver public services, which has required the strategic reconciliation or combination of the state and community logics.

In terms of pure community development work, [after a neighborhood management pilot project] we lost all the capacity. So when Community Organizing came along, it became an opportunity for us. We got on board with that program. It was all run through DCLG (Department for Communities and Local Government). Again, small amounts of money to do stuff, but we managed to maintain that program for three years, and that... We had three people doing community organizing in the area. (Director, Sheffield E)

Although community organizing practices suggest a clear invocation of the community logic through the emphasis on relationship building and empowering people to effect social change in their local area, the Community Organisers Programme was paradoxically a program designed and funded by the UK national government. As such, the state logic of centralization and bureaucracy is evident in the top-down design, implementation and evaluation of a community-based program.

\section{Narratives}

The narratives of the Sheffield case study organizations convey similar core priorities and beliefs. Directors articulated narratives about their organizations' origins as local community forums or informal groups of activists, which later became more professionalized and business-like with increases in funding, driving some to adapt or abandon their original more informal community-based processes of collaboration. Despite the fact that the European Objective 1 and SRB funding programs have ended, these narratives remain important in order to describe current values, strategies and priorities. Like organizational practices, the values and beliefs are drawn principally from the community logic, but also influenced by both the state and market logics, with an orientation toward effective service provision rather than a singularly political focus or ethos basis.

Beyond these common foundations and the values associated with these stories, the values and beliefs that define the narratives of the community regeneration organizations in Sheffield today have several similarities, as evidenced in their stated strategic aims and priorities. While there are differences in focus between the five organizations, what is consistent is the emphasis on local rootedness and support for disadvantaged communities. The narratives that support this mission vary, with
Sheffield B in particular invoking language and values corresponding to a social enterprise approach, suggesting the importance of both the state and market logics in order to achieve these core strategic priorities. This emphasis is further elaborated through the way Sheffield B defines its delivery model, which describes a client's pathway from community engagement to assessment or aspiration, through to empowerment, self-management and employment. This emphasizes the support role of professionals and the importance of the organization as a business to be responsive to client or customer demand.

The one thing I think that we all kind of collectively learned, we are a registered charity but we're not a charity in that we don't give money away. It has to stack up as a business. We need to be as smart and entrepreneurial as anybody else. It's really to do with, I think, the values that the organization has and you need to turn a surplus in order to deliver the service, based on the values that you hold dear to your heart. So we're not in it just to make money. We have to make money to achieve our social mission, which is different. (Director, Sheffield B)

In this quote, the director's narrative suggests that the organization defines itself according to social enterprise principles, where an organization uses trading or business activity as a means to achieve social or community ends (Evers and Laville 2004). The social enterprise logic that characterizes the ethos and values of Sheffield B and Sheffield C is something that Skelcher and Smith (2015) suggest emerges from a synergistic blending of the community, state and corporate logics. However, it is not clear to what extent these three logics are harmoniously combined in these cases, as even the more business-like of the community regeneration organizations experience a number of instances of conflict between these competing demands and identities, suggesting that they may be better categorized as assimilated hybrids.

Social enterprise values that contain an assimilation or blend of these three logics do not characterize all of the narratives expressed by the community regeneration organizations. Two of the organizations give an account of a decidedly community development approach-evidenced both in their strategic priorities outlined in documents and in interviewees' narratives. This was discussed in some detail in the discussion on practices, where we analyzed the ways in which these ideals were implemented in day-today activities. In terms of the values and beliefs, much of the narrative is supported by theory from Paolo Friere and Saul Alinsky, with the idea of valuing the contribution of individuals and, as one interviewee described, 'It's about challenging inequalities, tackling injustice. It's about working with people, not doing things to them' (Director, 
Sheffield A). The focus of these narratives is exclusively defined by the community logic, valuing trust, reciprocity and cooperation as main priorities. The values interlinked with the community development ethos are around empowerment, community cohesion and valuing the contributions of local people. The services that the organization delivers are seen as being instrumental in building social capital and local resilience, rather than being focused on delivering individual or personal outcomes.

Finally, most of the discourse expressed by three of organizations in Sheffield-Sheffield C, Sheffield D and Sheffield E-revolves around more general conceptualizations of 'community engagement,' which can be differentiated from the social enterprise and community development frames discussed above in that there is little emphasis placed on either the entrepreneurial or trading aspect (social enterprise) or challenging existing power relations (community development). Instead, the primary values and priorities of these organizations relate to being located 'in' the community, with links to local people and ongoing community engagement rooted in informal discussions.

There's a communication with local people that's much easier for us and there's so many, we can talk about how, but there just is... There are so many different ways, so by actually talking to people, actually knowing what's going on in their lives and being more in touch, being this kind of more whole person view because we're not a one service. That's not where we start from. We start from people's lives. We don't start from a service. (Former director, Sheffield C)

The values espoused here are quite general, but can be linked with the discourse and conceptualization of the nonprofit sector as a whole in the UK, where the role of volunteering and grassroots community activity is a focal point. The community logic, with legitimacy derived from unity of will and commitment to community ideology, is more evident here than the other narratives which demonstrate assimilation with the state and market logics.

\section{Discussion}

The evidence presented from our 10 case study organizations clearly demonstrates that the existence of differing logics and the interplay between these differ between the English and French cases examined. In order to interpret the findings and contribute to the theories of hybridity, we return to Skelcher and Smith's (2015) theoretical model of nonprofit hybrids. We argue that the institutional logics present in the English cases suggest that these are assimilated hybrids, which adapt their core state and community logics to the newer market logic (Table 2). In response to the changing political and funding landscape, these community regeneration organizations have adapted their narratives to respond to changes in rules, while attempting to maintain community-rooted practices. By contrast, the French social centers represent blended hybrids of the state and community logics, with virtually no influence of the market logic. Blended hybrids resolve the tensions between competing identities, structures and/or values espoused by the different logics that drive them by shaping these together strategically. The French hybrids demonstrate a unique type of logic blending, whereby the state logic is rendered into the local by means of a particularly French interpretation of the community logic.

In many ways, the analysis of the Sheffield organizations reinforces the existing literature on nonprofits and hybridity (e.g., Brandsen et al. 2005), and especially the expectation that they negotiate a space somewhere between the market, state and community logics. The assimilation of the market logic with those of the state and community in the Sheffield cases is clearly linked to their establishment through regeneration programs and the subsequent marketization of services requiring nonprofit organizations to adapt to government pushes to become more 'businesslike.' The complex assimilation of these three institutional logics by the Sheffield organizations confirms these theories and concurs with other recent studies of institutional logics and hybridity (Vickers et al. 2017).

Table 2 Institutional logics in England and France

\begin{tabular}{lll}
\hline & England & France \\
\hline Rules & $\begin{array}{c}\text { Primarily from contracts and funding arrangements (state or } \\
\text { market) which often conflict with practices and narratives } \\
\text { (community) }\end{array}$ & $\begin{array}{c}\text { Strong influence of government rules and policy but also formal } \\
\text { internal participatory democracy (Napoleonic State }+ \text { local } \\
\text { solidarity) }\end{array}$ \\
$\begin{array}{c}\text { Emphasis on service delivery (market or state) and becoming } \\
\text { more business-like (market) but also community engagement } \\
\text { (community) }\end{array}$ & $\begin{array}{c}\text { Combination of participatory democracy (Napoleonic state) and } \\
\text { reliance of volunteers and support of citizen-led projects (local } \\
\text { solidarity) }\end{array}$ \\
Narratives & $\begin{array}{c}\text { Social enterprise (state }+ \text { market }+ \text { community); or community } \\
\text { development and community engagement (primarily state and } \\
\text { community - difficult to reconcile with market) }\end{array}$ & $\begin{array}{c}\text { Solidarity, vivre ensemble, and application of values of the } \\
\text { French Republic (liberty, equality, fraternity) into local } \\
\text { context (Napoleonic state }+ \text { local solidarity) }\end{array}$ \\
\hline
\end{tabular}


Where our analysis contributes new knowledge is in four areas. First, it reveals how the assimilation of the three focal logics within nonprofit organizations is not a universal phenomenon. This prevailing tripartite description of hybridity is based on a generalized assumption of the application of New Public Management (NPM) principles in the public and nonprofit sectors. The French cases show that this ignores particular contextual conditions at the national level. While NPM was being promoted in the UK in the 1980s, France was undertaking a very different path of reforms, focusing more on rights, civil liberties and decentralization with little NPM influence (Elgie 2003). Our case analysis shows that social centers in France were established as a political and social project centered around specific values, and they have not been impacted by the same degree of marketization as have nonprofits in the UK. Through instituting an institutional logics approach, we can thus highlight the importance of historical contingency in the analysis of hybridity (Thornton and Ocasio 2008).

Secondly, our analysis of the French cases does not validate Skelcher and Smith's proposition that hybridization by blending logics is a response to environmental turbulence. In fact, the institutional environment in France is characterized by a higher degree of stability than the English cases, in the sense that the relationship between nonprofit organizations and the state has remained relatively unchanged over the last few decades. The logic blending that has resulted in the French nonprofits can be traced to the way in which they have engaged in concerted integration of state-like aims, discourses and ways of doing things into their local context.

Thirdly, the operationalization of institutional logics as rules, practices and narratives leads us to modify the literature on the impact of the value commitment of organizational members (Skelcher and Smith 2015) and the degree of centrality of different institutional logics (Besharov and Smith 2014). The analysis demonstrates that rules are considerably more important in defining the logics of the French cases than the English cases-overall, our coding showed a much higher incidence of discussions about rules in Lyon than in Sheffield. This finding is consistent with the typologies of administrative traditions, in which France is characterized as 'Napoleonic,' defined by a unitary state which favors bureaucracy and codification of standards and practices (Peters 2008). Formalized rules therefore are pervasive in structuring public and community life. By contrast, the UK is typologized as part of the Anglo-Saxon tradition, which sees the state as 'arising from a contract among members of the society' (Loughlin and Peters 1997, p. 50). This tradition accords greater significance to more informal mechanisms of negotiation between stakeholders, which may help to explain the relative disinclination to codify practices in the Sheffield cases.

Finally, practices in both countries demonstrate a greater influence of the community logic than the state or market, with more emphasis on cooperation and collaboration with citizens to achieve local change. This reflects the location of the organizations within the nonprofit sector, but the narratives used to describe the values, motivations and beliefs that justify these practices are driven by different conceptualizations of the voluntary and community (or associative) sector. The blending of the state and community logics that define the practices and narratives of the French social centers is derived from the French notion of the social and solidarity economy tradition, broadly understood as organizations that aim to benefit society, which are democratically governed and which privilege people over capital in the distribution of incomes (Evers and Laville 2004). In England, the sector is referred to as the 'charity' or 'voluntary and community sector,' highlighting the role of volunteering, donation and grassroots community activity to the relief of poverty (Taylor 2004).

\section{Conclusion}

For many years scholars have recognized hybridity as a characteristic of nonprofit organizations, but only recently has this observation been subject to theoretically informed empirical analysis. However, much of this work has been located within a single context, and so the propositions regarding hybridity have tended to take a universal form. In this article, we have employed an abductive research process to identify the combinations of and interplays between institutional logics in two countries, in order to better understand the degree to which different institutional contexts affect the way in which nonprofits respond to plural logics. Applying an institutional logics approach allows us to demonstrate that the organizations studied in France appear to diverge from the widely utilized model of the nonprofit organization as a hybrid that develops from the logics of the public, private and community sectors. There is considerable scope to develop such cross-national research in order better to refine our theorization of the way nonprofits develop and the policy and practice implications for their governance and operations.

Funding This study forms part of the corresponding author's doctoral research, which is primarily self-funded. $£ 1,900$ was received from the University of Birmingham School of Government and Society for fieldwork trips to Lyon in May 2015 and May 2016. 


\section{Compliance with Ethical Standards}

This study received full ethical approval from the University of Birmingham Humanities and Social Sciences Ethical Review Committee. Study participants have signed consent forms indicating that they were willing to take part in the research and have their interview audio recorded and transcribed, and that all quotes would be fully anonymized in research outputs.

Conflict of interest The authors declare that they have no conflict of interest.

Open Access This article is distributed under the terms of the Creative Commons Attribution 4.0 International License (http://crea tivecommons.org/licenses/by/4.0/), which permits unrestricted use, distribution, and reproduction in any medium, provided you give appropriate credit to the original author(s) and the source, provide a link to the Creative Commons license, and indicate if changes were made.

\section{References}

Battilana, J., \& Lee, M. (2014). Advancing research on hybrid organizing-Insights from the study of social enterprises. The Academy of Management Annals, 8(1), 397-441.

Besharov, M. L., \& Smith, W. K. (2014). Multiple institutional logics in organizations: Explaining their varied nature and implications. Academy of Management Review, 39(3), 364-381.

Bevir, M., Rhodes, R. A., \& Weller, P. (2003). Traditions of governance: Interpreting the changing role of the public sector. Public Administration, 81(1), 1-17.

Billis, D. (2010). Hybrid organizations and the third sector: Challenges for practice, theory and policy. Basingstoke: Palgrave Macmillan.

Binder, A. (2007). For love and money: Organizations' creative responses to multiple environmental logics. Theory and Society, 36(6), 547-571.

Brandsen, T., Van de Donk, W., \& Putters, K. (2005). 'Griffins or chameleons? Hybridity as a permanent and inevitable characteristic of the third sector. International Journal of Public Administration, 28, 749-765.

Cooney, K. (2006). The institutional and technical structuring of nonprofit ventures: Case study of a US hybrid organization caught between two fields. VOLUNTAS: International Journal of Voluntary and Nonprofit Organizations, 17(2), 143-161.

Elgie, R. (2003). Governance traditions and narratives of public sector reform in contemporary France. Public Administration, 81(1), 141-162.

Esping-Andersen, G. (1990). The three worlds of welfare capitalism. Cambridge: Polity Press.

Evers, A. (2005). Mixed welfare systems and hybrid organizations: Changes in the governance and provision of social services. International Journal of Public Administration, 28(9-10), 737-748.

Evers, A., \& Laville, J.-L. (2004). Defining the third sector in Europe. In A. Evers \& J.-L. Laville (Eds.), The third sector in Europe (pp. 11-42). Cheltenham: Edward Elgar Publishing Ltd.

Feldman, M. S., \& Orlikowski, W. J. (2011). Theorizing practice and practicing theory. Organization Science, 22(5), 1240-1253.

Feldman, M. S., Sköldberg, K., Brown, R. N., \& Horner, D. (2004). Making sense of stories: A rhetorical approach to narrative analysis. Journal of Public Administration Research and Theory, 14(2), 147-170
Friedland, R., \& Alford, R. R. (1991). Bringing society back. In: Symbols, practices and institutional contradictions. In W. W. Powell \& P. J. Dimaggio (Eds.), The new institutionalism in organizational analysis (2nd ed.). Chicago: University of Chicago Press.

Hantrais, L. (2008). International comparative research: Theory, methods and practice. Basingstoke: Palgrave Macmillan.

Hasenfeld, Y., \& Gidron, B. (2005). Understanding multi-purpose hybrid voluntary organizations: The contributions of theories on civil society, social movements and non-profit organizations. Journal of civil society, 1(2), 97-112.

Jäger, U. P., \& Schröer, A. (2014). Integrated organizational identity: A definition of hybrid organizations and a research agenda. VOLUNTAS: International Journal of Voluntary and Nonprofit Organizations, 25(5), 1281-1306.

Knutsen, W. L. (2012). Adapted institutional logics of contemporary nonprofit organizations. Administration \& Society, 44(8), 985-1013.

Kraatz, M. S., \& Block, E. S. (2008). Organizational implications of institutional pluralism. In R. Greenwood, C. Oliver, R. Suddaby, \& K. Sahlin-Andersson (Eds.), Handbook of organizational institutionalism (pp. 243-275). London: Sage Publications.

Laborde, C. (2000). The concept of the state in British and French political thought. Political Studies, 48(3), 540-557.

Loughlin, J., \& Peters, B. G. (1997). State traditions, administrative reform and regionalization in the political economy of regionalism (pp. 41-62). London: Routledge.

Lounsbury, M. (2007). A tale of two cities: Competing logics and practice variation in the professionalizing of mutual funds. Academy of Management Journal, 50(2), 289-307.

Lowndes, V., \& Roberts, M. (2013). Why institutions matter: The new institutionalism in political science. London: Palgrave Macmillan.

Minkoff, D. C. (2002). The emergence of hybrid organizational forms: Combining identity-based service provision and political action. Nonprofit and Voluntary Sector Quarterly, 31(3), 377-401.

Mullins, D. (2006). Competing institutional logics? Local accountability and scale and efficiency in an expanding non-profit housing sector. Public Policy and Administration, 21(3), 6-24.

Pache, A.-C., \& Santos, F. (2013). Inside the hybrid organization: Selective coupling as a response to competing institutional logics. Academy of Management Journal, 56(4), 972-1001.

Peters, B. G. (2008). The Napoleonic tradition. International Journal of Public Sector Management, 21(2), 118-132.

Reay, T., \& Hinings, C. R. (2009). Managing the rivalry of competing institutional logics. Organization Studies, 30(6), 629-652.

Reckwitz, A. (2002). Toward a theory of social practices: A development in culturalist theorizing. European Journal of Social Theory, 5(2), 243-263.

Rouban, L. (2008). Reform without doctrine: Public management in France. International Journal of Public Sector Management, 21(2), 133-149.

Salamon, L. M., \& Anheier, H. K. (1998). Social origins of civil society: Explaining the nonprofit sector cross-nationally. VOLUNTAS: International Journal of Voluntary and Nonprofit Organizations, 9(3), 213-248.

Scott, W. R. (2014). Institutions and organizations: Ideas, interests, and identities (4th ed.). London: SAGE Publications.

Skelcher, C., \& Smith, S. R. (2015). Theorizing hybridity: Institutional logics, complex organizations, and actor identities: The case of nonprofits. Public Administration, 93(2), 433-448.

Smith, S. R. (2014). Hybridity and nonprofit organizations: The research agenda. American Behavioral Scientist, 58(11), 1194-1508. 
Taylor, M. (2004). The welfare mix in the United Kingdom. In A. Evers \& J.-L. Laville (Eds.), The third sector in Europe (pp. 122-143). Cheltenham: Edward Elgar.

Thornton, P. H., \& Ocasio, W. (2008). Institutional logics. The Sage handbook of organizational institutionalism, 840, 99-128.

Thornton, P. H., Ocasio, W., \& Lounsbury, M. (2012). The institutional logics perspective: A new approach to culture, structure, and process. Oxford: Oxford University Press.
Timmermans, S., \& Tavory, I. (2012). Theory construction in qualitative research: From grounded theory to abductive analysis. Sociological Theory, 30(3), 167-186.

Vickers, I., Lyon, F., Sepulveda, L., \& McMullin, C. (2017). Public service innovation and multiple institutional logics: The case of hybrid social enterprise providers of health and wellbeing. Research Policy, 46(10), 1755-1768. 